\title{
Islamic Faith in Malaysia: Current Issues and Challenges
}

\author{
Associate Prof. Dr. Engku Ahmad Zaki Engku Alwi \\ Faculty of Islamic Contemporary Studies, Sultan Zainal Abidin University, Gong Badak Campus \\ 21300 Kuala Terengganu, Terengganu, Malaysia \\ Email: drkuzaki@unisza.edu.my \\ Nor Aini Abu Bakar \\ Academy of Language Studies, Universiti Teknologi MARA Kuantan Campus \\ Jalan Tanjung Api, 25050 Kuantan, Pahang, Malaysia \\ Email: noraini_abakar@pahang.uitm.edu.my \\ Roose Nilawati Subki \\ Academy of Language Studies, Universiti Teknologi MARA Kuantan Campus \\ Jalan Tanjung Api, 25050 Kuantan, Pahang, Malaysia \\ Email: roosensubki@pahang.uitm.edu.my
}

\section{Doi:10.5901/mjss.2014.v5n20p1954}

Abstract

This article discusses the current challenges concerning the faith of Muslims in Malaysia. Generally, there are two major challenges: the internal challenges and external challenges. These challenges are pressing and stressing the lives of Muslims. In order for Muslims to face these challenges, they need to have a very strong determination to stay true to the teachings of alQuran and al-Sunnah, for only these two can help safeguard the Muslims. Furthermore, both al-Quran and al-Sunnah act as major impetus towards community excellence in the various fields of life.

Keywords: Islamic Faith, challenges, the teachings of al-Quran and al-Sunnah

\section{Introduction}

Muslims around the world today face a variety of challenges that test their faith, belief and strength towards Islam. Muslims in Malaysia too have not been spared from these challenges in every aspect of their lives. One of the issues debated heatedly today is the vulnerability of the Muslims. Muslims in Malaysia now face a lot of setbacks in life, such as, poverty and disunity as well as many other problems and crises.

The situation now differs vastly from what is proclaimed in the Quran in which the Muslims are regarded as being the best role model for the global community in various aspects of life. Thus, what is wrong and who is to be blamed when the Muslims are forced to face the bitterness of life and wallow in a variety of crises and turmoil? (Engku Ahmad Zaki Engku Alwi 2007)

To answer this question, Muslims should reflect upon themselves and assess their Islamic faith, their deeds, their behavior and the pattern of their lives to see if they fully abide by the teachings of Islam. It should be emphasized here that there are many distinguished scholars who have analyzed this question in their books. They explain the calamities that have befallen the Muslims. Among them are Abu al-Hasan 'Ali al-Nadwi, Shaykh Muhammad al-Ghazali, Professor Dr. Yusuf al-Qaradawi, Mustafa Mahmud and others.

Prof. Dr. Yusuf al-Qaradawi (1985 7-21) concludes the situations that have befallen Muslims by saying that:

i) Muslims tend to forget that they are the best people,

ii) Muslims drown in materialism,

iii) Muslims are narrow minded, passive and follow others,

iv) Muslims' economic strength is dysfunctional,

v) Muslims are huge in quantity but weak in quality,

vi) Muslims' mentality is weak due to the emphasis on physical rather than spiritual strength, 
vii) Muslims' educational system and mass media do not support their character development.

Accordingly, Muhammad Qutb (1991 178-202) in his Ru'yah Islamiyyah Li Ahwal al-'Alam al-Islamiyy states that Muslims can never be successful in fulfilling the message of Islam as mandated unless they have sufficient material strength. The position of wasilah is akin to the proceedings of ghayah or goal directed. If a mandatory practice is not carried out unless with certain wasilah, then, that wasilah will be obligatory. Thus, how can Muslims present Islamic realization to the world if they are still dependent on the production of food from non Muslims and enemies of Islam? How can the Muslims rise to Jihad while they are still expecting arms from the enemies of Islam?

In fact, Allah has created this vast land for the use and convenience of all inhabitants of the world. In Surah alMulk, verse 15 Allah states that: He it is Who hath made the earth subservient unto you, so walk in the paths there of and eat of His providence. And unto Him will be the surrection (of the dead). Have ye taken security from Him Who is in the Heaven that He will not cause the earth to swallow you when lo! It is convulsed? So, why is the rest of mankind enjoying the produce of the earth, whereas the Muslims still live in a destitute state of poverty and lagging behind when the wealth of their land has been confiscated by the enemies of Islam? (Muhammad Qutb1991 178-202) .

Muhammad Qutb expresses surprise at how the Muslims are beset by weakness, poverty, squalor, astray and lagging behind in various fields of life while all over the world Allah has laid for them sources of strength, power and endurance (Muhammad Qutb1991 178-202).

Eventually, Sheikh Muhammad Qutb (1991 178-202) reveals that the exact cause of the weaknesses of Muslims is in fact a divine punishment meted out to the Muslims due to the negligence and carelessness of their own accord. Muslims are weak and lagging behind as they fail to observe Islam as the reality of contemporary life. This is consistent with the Quran in Surah Taha, verse 124 which means: And whoever turns away from remembrance of Me, his will be a narrow life, and I will raise him on the day of Resurrection blind.

Dr. Salah Abd al-Fattah al-Khalidi (1989 16) mentions about Muslims today by saying:

Who are we? Let us honestly acknowledge that Muslims in the present age are the worst example in the history of Islam. In fact, Muslims are ignoring Islam as the core of their lives so much so they are now leading extraordinary lifestyles. Besides that, they are also marginalizing Islam in various aspects especially in the field of religion, values, morality, mysticism, objectives, methodology, politics, economy, knowledge and practices.

Abd al-Qadir Awdah also mentioned that:

The actual weaknesses of Muslims are not due to the rules and laws of Islam; rather it is due to marginalizing Islam in their life. Thus, Muslims in every corner of the Muslim nations are just Muslims by name only, not Muslims that are rooted in faith and righteousness except those whom Allah blessed and their number is very small .... . (Mahmud Ismail et.al t.t. 133)

In her book, Rihlah min al-Masjid ila al-Kanisah Limadha?, Mary Weliderz (formally a young Christian woman) (1992 42) from Britain mentions that:

The administrative pattern practised in most Islamic countries and the following misconduct or activities by some Muslims themselves have left a very deep impression among the Westerners about Islam. How can we explain the brutal attacks against civilians in the war that broke out between Iraq and Iran? Besides, the behavior and activities of some Muslim immigrants to the West have aggravated the image of Islam. Because of these behavior and activities, the negative aspects of Islam have been widely tarnished through the mainstream channels of newspapers, magazines, television, radio and films. Thus, this would make a strong reason for the West to urge their people to go against the Muslim community and strengthen their belief and hatred towards Islam...... .

Muhammad Qutb (1988 279) describes them as people who hate Islam:

Nevertheless, there are people who do not hate Islam in terms of faith, but rather they do not like to practise the teachings of Islam in their life. This group of people only believes in prayers and fasting. They do not have the faith or the strength to practise other Islamic rituals. What they want is unlimited pleasure! They just want to have fun in watching pornographic movies at the cinemas, dances on television, which may be halal or haram. Some of the men enjoy watching women spreading defamation on the streets! Egoistically these women would entice the men with their extreme feminity by dressing up and putting make-up extravagantly. This group of people too, feels that they have done nothing wrong as long as their intentions are clean and correct. Thus, it is clear that the Islamic faith is not deeply rooted in them as they believe that it is sufficient to just perform the prayers and fasting. To make Islam the way of life, people need to abide by its rules in their daily life such as in dressing, eating and complying with all other matters pertaining to 
living in the name of Allah. Though they do not resent Islam openly but they are the ones who actually harbor deep hatred towards Islam.

Indeed, this is the reality and the scenario of the Muslims now. There is no point in feeling proud about being Muslims when they are actually lagging far behind in all aspects of life and are easily fooled and suppressed by the enemies of Islam. In fact, Islam considers these weaknesses as crimes that are being committed by Muslims themselves since they go against the order of the Quran and the Hadiths.

\section{Current Challenges In Malaysia}

In the Malaysian context, the government has outlined 10 key principles of Islam Hadari, which will also be the 10 challenges faced by Muslims:

i) Faith and Piety to Allah

ii) Just and Honest Government

iii) Liberated People

iv) Mastery of Knowledge

v) Comprehensive and Balanced Economic Development

vi) Quality Life

vii) Protection of the Rights of the Minority Groups and Women

viii) Cultural and Moral Integrity

ix) Conservation of Nature

x) Strong Defense

Islam Hadhari emphasizes the aspects of civilisation and development which focus on enhancing the quality of life through the mastery of knowledge, human, health and physical development. To upgrade the quality of life, a balanced and integrated economic and trading system as well as a dynamic financial system must be implemented. This is to produce a knowledgeable, pious, civilized, ethical and honest community who is able to take on global challenges. Islam Hadhari is not a new sect. It is, in fact, an effort to bring the Ummah back to basics or fundamentals as found in the Quran and the Hadith, which form the foundation of Islamic civilization. If Islam Hadhari is understood and interpreted sincerely and clearly, it will not cause any Muslims to deviate from the true path. As a government that is responsible to protect the sanctity of Islam and to ensure that the Muslims do not deviate from their faith, able to meet the challenges and realities of time, the door of iitihad must be opened to interpretation that will shape the pattern of current development. The various approaches and methods covering the development of infrastructure and economic development must be reviewed. It must be more balanced and comprehensive in order to strengthen human development through a comprehensive educational program, complemented with spiritual development programs to inculcate good Islamic values in life. (Engku Ahmad Zaki Engku Alwi 2007)

Salleh Buang (2006) also outlines 10 challenges currently faced by Muslims:

i) To implement the unfinished Malay / Muslims agenda.

ii) To maintain the status and direction of the Syariah Court.

iii) To restore public confidence in the Syariah judicial institutions of the country.

iv) To strengthen and improve the government departments and public agencies, including that of the Islamic Affairs Department.

v) To address the influence of the "Global Christianity".

vi) To continue with the abandoned Malaysian common law project.

vii) To renew / refine the state law that is inconsistent with the Islamic law.

viii) To renew outdated laws that are no longer appropriate in the new millennium.

ix) To practise sustainable development in controlling the misdirected development.

x) To strengthen / implement environmental laws.

A Mufti on the other hand, feels that some of the challenges faced by the Muslims in Malaysia are as follows:

i) the transfer of Western culture

ii) secularism

iii) hedonism culture

iv) pluralism

v) outbreak of AIDS / HIV (Engku Ahmad Zaki Engku Alwi 2007)

A Muslim youth organization (ABIM 2006) identifies six other challenges faced by Muslims in this country: 
i) liberalism

ii) the Western hegemony

iii) political morality

iv) madani society

v) national unity

vi) strengthening the racial moral issues

Overall, it can be concluded that Muslims in Malaysia are facing a variety of challenges that can ultimately be classified into two different challenges: challenges that come from within the Muslim society itself and the external challenges especially those from the West.

\section{Challenges within thE Muslim Society}

Among the challenges that come from within the Muslim society are ignorance and lack of appreciation of the Muslims towards Islam, especially Islamic faith. Various forms of crises and turmoil pertaining to faith among the Muslims are signs and yardsticks to determine the level of vulnerability of Muslims towards religious knowledge and their ability to distinguish right from wrong.

For example, Muslims that are trapped in heresy are very vulnerable in believing and accepting deviant teachings which are clearly contradicting the beliefs and tenets of Islam such as:

i) To legalize forbidden things which are clearly stated haram by Allah.

ii) To believe in the existence of on-going revelation.

iii) To believe in other prophets and apostles after Prophet Muhammad (pbuh).

iv) To believe in teachers as the Imam Mahdi or the prophets.

v) To believe that the dead can provide assistance when called upon.

vi) To nullify certain requirements of the Islamic Syariat such as prayer, fasting, zakat, hajj, etc. (Islamic Affairs Division 1994).

Such aberrant beliefs are clearly contrary to the tenets of the Islamic faith which are the required knowledge to be learned and believed. These have never been disputed by any Muslims in this world except those who are heretic and influenced by deviant teachings.

Therefore, ignorance towards Islam is a major factor in the crisis of faith among Muslims which causes the emergence of deviant teachings. Normally, the ignorant would fully accept things without thinking critically about the truth. (Engku Ahmad Zaki bin Engku Alwi 2014).

Thus, the emergence of contrary teachings in Islam is due to this ignorance in beliefs, tenets and some other areas in Islam. Ignorant people are those who do not know anything. When things are explained to him, he would consider the matter correct without any thinking. Ignorance can be harmful if it involves faith. This is because it is difficult to change their mindset in a short period of time as reformation would be a long and continuous process. (Azhar Abu Samah \& Mohd Yusof Sulaiman 2000 28).

Ignorance can also be the cause of the misunderstanding among Muslims about the teachings of Islam. According to Kamus Dewan misunderstandings are defined as 'do not understand the reference to the real thing or a sense of wrong, wrong or misconstrued to mean something' (Kamus Dewan 2002 1174).

Muhammad Qutb (1989 55) asserts that, misunderstanding Islam means not understanding the true meaning of Islamic divinity, the universe as well as humanity. In other words, there is a misconception in human thinking in response to divinity and the relationship between man and God. This is also extended to the misconception between the universe, mankind, God and the reality of life. In short, human misunderstanding of Islam encompasses all fields of human life such as beliefs, syariat and morals.

Apart from ignorance, misunderstanding can occur when a person does not gain Islamic knowledge from the original source of the Quran and the Sunnah. Al-Quran and al-Sunnah are the only true main sources of reference in understanding the real nature of Islam. Muslims can easily misinterpret Islam if they refer to other sources. (Muhammad Nor bin Ibrahim et al. 14-15 1995).

In this regard, the Prophet said which means: Allah's Messenger said: I leave behind me two things that you will never go astray as long as you hold tight to them, which is the book of Allah and the Sunnah of His Prophet.

The weaknesses currently faced by the Muslims are due to the lack of awareness, forgetting their roots, not maximizing their strength and potential, not independent and too dependent on the West. Besides, today's Muslims are narrow and rigid in their thinking, adverse in taqlid culture, fading spiritual strength, not knowledgeable, highly lacking of ideas, low morality, weak comradeship, poor work quality, less productive and extremely permissive in allowing own 
economic resources be exploited by enemies (Yusuf al-Qaradawi, 1985 10).

Misunderstanding of Islam also arises due to the intellectually weak Muslims. These Muslims do not understand the true meaning of Islam as desired by Allah (swt) and His Messenger which leads to confusion. Due to low self-esteem in the ideologies of the world, they then similarised Islam with these ideologies. This leads to the terms "Islamic socialism", "Liberal Islam", "Islamic capitalism", "Islamic democracy", "Islamic humanism" and other terms alien to Islam. Thus, many people assume that Islam is commensurate with man-made ideologies (Hilmy Bakar almascaty 1994 23).

Actually, the major weakness of the Muslim world today is not because of strong enemy attacks or their efficient strategic planning, but because of their wisdom in taking advantage of problems, shortcomings and internal weaknesses of the Muslims. One thing that is certain is, since $12 \mathrm{H} / 18 \mathrm{AD}$ till $13 \mathrm{H} / 19 \mathrm{AD}$, the Muslim world was plagued by ignorance and stagnant mind syndrome. Islam today is only in the name and thus has subjected it to the adulteration of thoughts, culture, politics and military. This western attack is considered as a revenge of their defeat in the Crusades that lasted for nearly 200 years (Hilmy Bakar almascaty 1994 23).

\title{
4. Challenges of the West
}

In these modern times, intentionally or otherwise, there are many malpractices of faith in every aspect of Muslim life. Thus, it is the misappropriation of faith which is quite complicated to be corrected. One type of abuse of faith in these modern times is to free oneself from the bondage of religion. This situation occurs when a Muslim feels that Islam is an aspect of life that can be ignored because of self-interest and the current situation. Religion tends to be set aside when one feels that it is no longer required to fulfill the ambition of his/her life (Wan Mohd Azam Mohd Amin 1995 21).

Another misconception of faith in Islam is that one feels that Islam is a religion that is too good, therefore, it cannot be mixed with worldly affairs such as social affairs, politics, economics and others (Wan Mohd Azam Mohd Amin 1995 21).

Both these misconceptions were in fact also present in previous divine religions before Islam, namely among the Jews and the Christians. Divinity thoughts and all its teachings are marginalized from everyday life in this world. This is termed as secularism. Prof. Syed Muhammad Naquib al-Attas (1978 15) in his book Islam and Secularism cites a famous definition of secularism:

\begin{abstract}
"The deliverance of man "first from religious and then from metaphysical control over his reason and his language". It is "the loosing of the world from religious and quasi-religious understandings of itself, the dispelling of all closed world views, the breaking of all super natural myths and sacred symbols"... the "defatalization of history", the discovery by man that he has been left with the world on his hands, that he can no longer blame fortune or furies for what he does with it...; (it is) man turning his attention away from worlds beyond and toward this world and this time". Secularization encompasses not only the political and social aspects of life, but also inevitably the cultural, for it denotes "the disappearance of religious determination of the symbols of cultural integration
\end{abstract}

It is clear from the above definition that secularism is an ideology that is anti-religion and anti-God. In the course of modern world history, modern Western-oriented secularism has succeeded in secularising the world, including the Muslim world. Simply put, the process of secularization is actually not more than a process of human emancipation from the shackles of religious and metaphysical control.

The modern Western civilization has created in the Muslims enthusiasm, understanding, ideas and world view that are not compatible with the world view and goals of Islamic civilization. This is because, the context of modern Western civilization disregards God and emphasizes more on material (Sidi Gazalba 1973 22).

In other words, modern Western civilization is a civilization that emphasizes the individualistic element in a lifestyle as it is also rooted to materialistic notion of a belief. That is to say, the attitude to life focuses on the search for material enjoyment alone. People are willing to risk their lives for material things. This obsession leads to the rejection of other noble values. (Muhammad al-Bahi in 1979 11).

In addition, modern Western civilization is also dominated by the notion of secularism. This notion refers to an attitude that leads to ignoring the question of God and all religious activities because of all worldly things, and people do not have time to think about the Hereafter (Muhammad Naquib al-Attas 1978 17).

From the psychological implications, the West has successfully inculcated the domination of values, materialism over the concepts, doctrine and the way of life in Islam. This defeat by the West is eroding the image of Islam and in turn restores it back to that of ignorance. All aspects of Islamic way of life such as education, science, economy, finance, military, art, social, culture and mass media have been affected by this defeat. (Muhammad Naquib al-Attas 1978 4951).The defeat has a very serious impact on the education sector. The teachings of engineering, psychology, sociology, 
biology, astronomy, physics, chemistry, mathematics, economics and medicine in educational institutions have been far removed from the spirit of Islam eventhough the founders and pioneers of all these knowledge were Islamic scholars. What is worse, the Muslim students have to refer to the Western facts or theories that are sometimes in conflict with the teachings of Islam. This has caused many of these students to blend with the Western civilization Qibla in terms of thinking, values, identity, tastes, trends and lifestyle. (Muhammad al-Ghazali 1991 37).

It has always been the ambition of the West to make everyone in this world live in the same culture, think alike, has the same personality and faith, history, culture, past civilization, education and traditional values. The West too would like to produce Westernized secular Muslims void of Islamic morality. These secular Muslims are Muslims in the name only. Their values and world view of religion, way of life, people, history, faith or belief in the power of Islam are diverted to that of the West. Even their perception of the legal system, politics, morality and culture has also changed. This is reflected in the behavior, actions and thoughts through their various speeches and writings (Muhammad al-Ghazali 1991 70-72).

This leads to the emergence of various ideologies such as secularism, capitalism, nationalism, socialism, and so on replacing Islam as a way of life (Solomon 1995 165-174). Consequently, Islam was isolated away from the realities of life, and some even consider the modern ideologies such as secularism and nationalism as part of Islam.

Today, the Islamic community witnessed the dumping of printed materials and publications on daily, weekly, monthly or annually basis, all of which accommodate a variety of issues and questions of life such as the question of divine humanity, family, education, politics, economics, and humanitarian and consumerism. Dumping of such materials is not only produced by the local community, but also by that of the foreign media promoting Western cultural influences which eventually dominate every aspect of the Muslim life. (Engku Ahmad Zaki Engku Alwi 2007)

The use of advanced technological equipment channels has reinforced the values of western civilization that were instilled in the colonial period with a number of new values added that brought to the postmodern era known as postmodernism. Basically, this postmodern marvel is marked by the universality elements of the planet earth. In the sense of universality as expressed by Marshal McLuhan, the world is just a village which has successfully crossed all borders and restrictions that were created since the emergence of the nation-state of about 500 years ago. All these are estimated to be probably the result of the last great revolution in information technology and computers that are affiliated with telecommunications and satellite technology. This is exactly the essence of what is declared by Kenichi Ohmae in his discourse "borderless world" that marks the end of the modern era to be replaced with postmodern (Anwar Ibrahim in 1995 1-2).

The intensity of information technology, computers, telecommunications and satellite technology will dominate the scope of far-flung regions of human daily life today. This means that any society on planet earth will be exposed continuously to the breakthrough of any form of foreign publications without any screening. Censorship and control by the authorities of a nation will be very difficult to administer as the advanced technology has made broadcasting and disseminating of materials possible universally. The dissemination of this kind of materials will be the catalyst to weaken the differences and cultural diversity of the community and that of other communities in the world (Anwar Ibrahim in 1995 1-2)

If colonialism was the main aid to disseminate the old edition secularism, then, the sophistication and power of computers, information technology, telecommunications and satellite technology are like right wings that help in the spreading of the latest secularism edition, turning the world into a global village. In this situation, we are thus, instantly reminded of televisions and computer monitors that are common sights in Muslim households today. In fact, television has become part of the family. In addition, we are also reminded of the terms like the internet, the information highway, parabolic disc and open sky. These are advanced hardware equipment or disseminators of postmodernism to produce a new form of colonialism edition (Rahmah Hashim 1995 6).

At present, the variety of equipment such as television and its programs act as a very influential social institution. It is capable of shaping the culture, nourish and strengthen the range of values, attitudes and specific behaviors that have already been formed. It is also capable of transforming lifestyles, changing and shaping the pattern and mode of relations among families, colleagues and the community at large (Rahmah Hashim 1995 6).

Negative social behavior is easily assimilated by the younger generation not through religion but through the imported Western culture. They are comfortable with the pop, rock and rap cultures and are more familiar with their performers than the companions of the Prophet (pbuh) and Islamic scholars. Programs such as Pop Quiz, Asia Bagus, Top of the Chart, Top Ten, Entertainment This Week and others are just mere entertainment which does not help in developing young intellectuals. When these unwanted elements occur, the Eastern culture and religion will eventually be lost forever (Liz Wan Wan Omar Othman 1993, 34).

Entertainment, now, seems to be the essence in the life of teenagers. $60 \%$ of the programs on radio and television channels are focused mainly on entertainment. Performances of international concerts from abroad bring with them their 
culture and entertainment. For example, a music group from Germany, The Scorpions has rocked Stadium Merdeka in mid-September 2004. A few days later another concert named "The Best of Blue" was held at Bukit Kiara. In short, Western bands are brought into Malaysia every year.

The greatest impact in our younger generation today is that they lose confidence in themselves. This lack of confidence syndrome is reflected in their fanatic obsession of Western fashion and behaviors. The young generation does not have a personality of their own as they tend to imitate other people's image (Indriaty Ismail 1999 113).

Ironically, the hedonist entertainment culture which is not approved by the teachers in the school, is allowed outside the school. Young children always love entertainment and fun. This hedonist entertainment gets carried away in schools when students discuss the artists, concerts, songs, dances, costumes and artists' behavior. Daily lessons especially religious education becomes rigid and is ignored. (Engku Ahmad Zaki Engku Alwi 2014).

Printed media, especially decadent entertainment magazines featuring superstitious stories, contribute to a wide and extensive coverage that spread throughout the country. This is complemented by the complete commentaries on foreign films, video games and musical development abroad. The entry of these wild foreign cultures and anti religion has spread among the Islamic community without being noticed. The younger generation today is immune to irreverent use of language and the practices that are in conflict with religious values. This can be observed through their disobedience towards their parents, family or teachers, drug addiction, free mixing of men and women and others (Indriaty Ismail 1999 $116-117)$.

\section{Solutions from the Perspective of Islam}

Considering such great challenges faced by the Muslims in Malaysia, effective strategic solutions should be identified as a strong defense to repel any attacks. In such situations, Muslims have often heard calls from various parties to return to the Quran and Sunnah of Prophet Muhammad (pbuh). The question now is, how do we go about going back to the Quran and al-Sunnah? The answers to this are very much sought-after by every Muslim in order to survive the current challenges.

The Dakwah Movement and the purification of the faith must be expanded through a wide range of educational institutions and agencies in the country. Purification movements and strengthening of faith should be implemented intergratedly through education at all levels, primary, secondary and tertiary. Appropriate curriculum on faith that caters to the current situation should be provided. Refining of this faith movement should also be extended through the mosques in the country.

Maximize and effectively use media whether electronic or printed and information technology in Islamic missionary work in strengthening the Islamic faith. They can also be tools to expose heretic activities in the community. This is because the mass media is a wide channel which is easily accessible by the public. Thus, it is the most appropriate channel to be used by religious authorities as a means of spreading Islamic values.

The seriousness of preaching responsibilities in overcoming the crisis of faith is not only affecting the community locally but also universally. The role of Islamic preaching institutions should be evaluated and reviewed in terms of their objectives, approach or preaching techniques, media or missionary equipment and goals to ensure the effectiveness and success of their roles. By increasing the number of missionaries and giving them appropriate training, they can face the society with wisdom and tact in giving guidance and religious education to meet their needs and development.

In the context of Islamic education, there are two levels of concern. The first level is the informal Islamic education which requires review and strengthening of the curriculum, methodology, textbooks, teacher training, evaluation, finance and management. The weaknesses found need to be addressed urgently to be in consistent with the objectives of basic education that is to produce quality human capital who could withstand a variety of challenges. The second level is a need for a comprehensive review of the formal Islamic education. Can the basis of the religion currently offered have a better impact on students? This is because many factors concerning the basic Sharia are not visible. To understand these invicible factors requires its own approach which is articulative in manner. This is because the 11 years of Islamic education in schools should be able to instill spiritual strength and fikriah in the students.

Al -Ghazali advocated an approach which emphasizes the belief that education must be taught to children and the general public in a way that all the intricacies of the content of the faith must be implemented through the following four stages :

i) must begin with memorizing

ii) must gradually understand the meaning of the contents of the faith revealed

iii) must solemnize iktikad

iv) then tasdiq with confidence 
Non-formal education dedicated to the public:

i) Formulating an Islamic education curriculum dedicated to the public so that they continue to adhere to the teachings of Islam, especially knowledge on faith to act as a strong shield to face the threat of deviant teachings.

ii) Using the mosques and musollas as a centre of Islamic learning and continuous education so that they can continue to embrace Islam as a complete way of life. This is done through increasing the number of Islamic religious classes at the mosques and musollas to strengthen their knowledge of Islam.

iii) Establishing Islamic education as a process of continuous education compulsory for the Muslim community, especially for the young school leavers and university graduates. This is because, in Islam there are no constraints of age nor socio-economic position to acquire knowledge. In fact, Islamic tradition education is a lifelong learning observed throughout one's life, in all circumstance and endeavors.

Mobilizing energy and enhancing community awareness of the importance of preserving the purity of the faith as well as motivating them to engage in the movements of purification and strengthening of faith within their respective ability. All Muslims should urge fellow members to highlight and utilize the facilities available at the mosques and those at the Islamic learning centers in order to strengthen their faith.

To train the youngsters to familiarize themselves with the mosques and other Islamic centers of education. This is to strengthen their faith, prayers and morality in everyday life as well as to train them to lead religious ceremonies held in their area.

The government as the leadership trustee must implement the trust fairly on equitable basis, especially in the execution of all orders and prohibitions contained in the Quran and the Sunnah of the Messenger of Allah. Islam will not prevail as strong and powerful in Muslim community through exquisite slogan or rhetorical utterances only, but it demands the implementation of Islamic teachings in every aspect of life. In other words, Islam is not confined to the prayers, munakahat and muamalat alone, but Islam is holistic in nature which covers all aspects of life including politics, crime, community and others.

\section{Conclusion}

Based on the above, Muslims must adhere to the Quran and the Sunnah in facing the current diverse challenges. Islam is not simply a rhetorical slogan uttered everywhere. Instead Islam demands the implementation of a comprehensive way of life in order to regain the status of Muslims as the best human race on earth.

\section{Referrences}

Al-Khalidi, Salah Abd al-Fattah, Dr. (1989), Thawabit Li al-Muslim al-Muasir. Kaherah: Maktabah al-'Ulum al-Islamiyyah, Suwailih wa Dar al-Isra'.

Anwar Ibrahim (1995), "Kesejagatan dan kebangkitan Bangsa" dalam Pemikir, bil. 2, Oktober-Disember 1995.

Azhar Abu Samah dan Mohd. Yusof Sulaiman (2000), "Jahil Agama Punca Akidah Terpesong" dalam Berita Harian, Jumaat 13 Oktober 2000.

Bahagian Hal Ehwal Islam (1994), Kriteria Dalam Ajaran Sesat, Kuala Lumpur: Percetakan Nasional Malaysia Sdn. Bhd.

Engku Ahmad Zaki Engku Alwi (2014), Heresy in Malaysia: An Analysis. La Pensee. Volume 76, issue 1. Pensee, Paris, France.

Engku Ahmad Zaki Engku Alwi (2010), Ajaran Sesat di Malaysia: Satu Analisis. Jurnal Peradaban. Vol. 5. Pusat Dialog Peradaban, Universiti Malaya.

Engku Ahmad Zaki Engku Alwi (2007), Cabaran-cabaran Semasa Umat Islam dan Penyelesaiannya Menurut Agama. The Malaysian Journal of Social Administration. Vol. 4. Jabatan Pentadbiran dan Keadilan Sosial, Fakulti Sastera dan Sains Sosial, UM.

Hilmy Bakar Almascaty (1994), Ummah Melayu: Kuasa Baru Dunia Abad ke-21. Kuala Lumpur: Berita Publishing.

Indriaty Ismail (1999),"Antara Media dan al-Quran: Pengaruh dan Kesan Dalam Pembentukan Peribadi Masyarakat Islam Malaysia Masa Kini" dalam Muda @ Ismail Abdul Rahman et. al. (1999), Cabaran Islam Di Abad Ke-21. Kuala Terengganu: Yayasan Islam Terengganu.

Kamus Dewan. Kuala Lumpur: Dewan Bahasa dan Pustaka. Edisi Ketiga. 2002. h. 1174.

Mary Weliderz (1992), Rihlati min al-Kanisah Ila al-Masjid Limaza. Misr al-Jadidah: Maktabah al-Nur.

Muhammad al-Bahi (1979), Islam Dilitupi Awan Mendung, Yusoff Zaky Yaacob (terj.), Kota Bharu: Syarikat Dian. Sdn. Bhd.

Muhammad al-Ghazali (1991), Kayfa Nafhamu al-Islam, al-Iskandariyyah: Dar al-Da'wah.

Muhammad Nor b. Ibrahim et al. (1995), Muqaddimah Mastika Hadis Rasulullah (s.a.w.), Kuala Lumpur:Bahagian Hal Ehwal Islam, Jabatan Perdana Menteri.

Muhammad Qutb (1989), Jahiliyyah al-Qarn al-'Isyrin, Kaherah; Dar al-Syuruq.

Muhammad Qutb (1991), Ru'yah Islamiyyah Li Ahwal al-'Alam al-Islamiyy. Riyad: Dar al-Watan al-Nasyr. 
Muhammad Zakariyya al-Kandahlawi (1980), Awjaz al-Masalik Ila Muwatta' Malik, Kitab al-Jami', Bab al-Nahy 'An al-Qawl bi al-Qadr, j. 14, no. Hadith: 1395, Beirut: Dar al-Fikr.

Rahmah Hashim (1995),"Kelangsungan Generasi di Bawah Langit Terbuka", (Kertas Kerja Simposium Penyelidikan Komunikasi ke-4, Universiti Kebangsaan Malaysia, 5-6 September 1995).

Salleh Buang (2006), Sikap dan Peranan Umat Islam Dalam Menghadapi Cabaan Semasa. (Kertas Kerja yang dibentangkan dalam Simposium Pengurusan Hal Ehwal Islam Peringkat Kebangsaan di Pusat Konvensyen Antarabangsa Putrajaya Anjuran Jabatan Kemajuan Islam Malaysia pada 20 November 2006).

Sidi Gazalba (1973), Modenisasi Dalam Persoalan: Bagaimana Sikap Islam, Jakarta: Bulan Bintang.

Sulaiman Nordin (1995), Islam, al-Quran dan Ideologi Masa Kini, Kuala Lumpur: Dewan Bahasa dan Pustaka.

Syed Muhammad Naquib al-Attas, Prof. Dr. (1978), Islam and Secularism, Kuala Lumpur: Muslim Youth Movement of Malaysia.

Wan Liz Othman Wan Omar (1993), "Membentuk Bangsa Yang Berperibadian Besar" dalam Dewan Masyarakat, Disember 1993.

Wan Mohd Azam Mohd. Amin, Dr. ( 1995),"Penyelewengan Akidah Dalam Kehidupan" dalam Dakwah, bil. 218, tahun XVI, Julai 1995 Yusuf al-Qaradawi, Dr. (1985), Ayna al-Khalal, Kaherah: Dar al-Sahwah.

Yusuf al-Qaradawi, Prof. Dr. (1985). Ayna al-Khalal. Kaherah: Dar al-Sahwah. h. 7-21.

Zakaria Stapa, Prof. Madya (1999), Tasauf: Menjana Personaliti Umat Abad ke-21, Kuala Terengganu: Yayasan Islam Terengganu. 